УдК 615.32

\title{
ОПРЕДЕЛЕНИЕ СОДЕРЖАНИЯ КСАНТОНОВ И ЭЛЕМЕНТНОГО СОСТАВА НАДЗЕМНОЙ ЧАСТИ И ЭКСТРАКТА IRIS LACTEA PALL *
}

\author{
(C) E.A. Антипова ${ }^{1}$, E.A. Лейmес ${ }^{2 *}$
}

${ }^{1}$ Алтайский государственный медицинский университет, пр. Ленина, 40, Барнаул, 656038, (Россия), e-mail: vtby@mail.ru

${ }^{2}$ Алтайский государственный университет, пр. Ленина 61, Барнаул

656049, (Россия), e-mail: leites-elena@yandex.ru

Iris lactea Pall (ирис молочно-белый) относится к роду Iris L. семейства касатиковых Iridaceae. В виде травы или экстракта Iris lactea Pall находится в составе некоторых биологически активных добавок, входит в состав мази «Алпизарин», использующейся в качестве противовирусного средства. Применение противовирусных препаратов растительного происхождения - наиболее безопасный способ лечения, учитывая, что герпесом поражено около 90\% населения. Данные по элементному составу травы и экстракта Iris lactea Pall в литературе отсутствуют.

Цель работы - определение содержания ксантонов и элементного состава травы и сухого экстракта Iris lactea Pall.

В статье представлены результаты определения основных групп действующих веществ. Методом атомно-эмиссионной спектрометрии с идуктивно связанной плазмой определено количественное содержание $\mathrm{Cu}, \mathrm{Fe}, \mathrm{Ca}, \mathrm{Co}, \mathrm{Ti}, \mathrm{Se}, \mathrm{V}, \mathrm{P}, \mathrm{B}$, $\mathrm{Na}, \mathrm{Mg}, \mathrm{K}, \mathrm{Al}, \mathrm{Ba}, \mathrm{Sb}, \mathrm{Ag}, \mathrm{Sr}, \mathrm{Sn}, \mathrm{Mo}, \mathrm{Ni}, \mathrm{Cd}, \mathrm{Pb}, \mathrm{As}, \mathrm{Zn}, \mathrm{Be}, \mathrm{Mn}, \mathrm{Cr}$, при этом количество тяжелых металлов и мышьяка в траве и экстракте не превышает их предельно допустимое содержание в лекарственных растительных препаратах. Методом тонкослойной хроматографии определены ксантон алпизарин и флавоноиды - рутин и кверцетин. Методом высокоэффективной жидкостной хроматографии (ВЭЖХ) установлено наличие алпизарина и родственных ксантонов.

По разработанной методике определения ксантонов методом ВЭЖХ, предлагаемой в этой статье, наибольшее содержание ксантонов, в пересчете на алпизарин, составляет в траве касатика молочно-белого - 1.14\%, а в экстракте сухом $1.79 \%$. Экстракт и трава ириса молочно-белого являются перспективным источником для разработки препаратов, подавляющих размножение вируса простого герпеса и его подтипов.

Ключевые слова: Iris lactea Pall, надземная часть, алпизарин, апигенин, кверцетин, лютеолин, рутин, кверцетин, герпес.

\section{Введение}

Iris lactea Pall (ирис молочно-белый, или касатик молочно-белый) относится к роду Iris L. семейства касатиковых Iridaceae, распространен на Дальнем Востоке, Восточной Монголии, Северо-Восточном Китае. В степной зоне Восточного Забайкалья произрастает на солонцеватых берегах рек, озер, родников, засоленных сухих лугах, солончаковых бугристых болотах. Ирис молочно-белый может расти на чрезвычайно уплотненных грунтах, часто зарослями, цветет в конце мая - начале июня $[1,2]$.

В виде травы или экстракта Iris lactea Pall входит в состав некоторых биологически активных добавок, замедляющих процесс старения («Витонг», сироп «Голубой берилл»), чаев, применяемых для повышения иммунитета. В гомеопатической практике ирис используется при лечении мигрени, желудочных заболеваний с коликами [3-13].

Как известно, применение растений в медицине обусловлено содержащимися в них полифенольными соединениями - флавоноидами. Одним из основных действующих веществ Iris lactea Pall является ксантон

Антипова Екатерина Алексеевна - доцент, кандидат медицинских наук, e-mail: vtby@mail.ru

Лейтес Елена Анатольевна - доцент, кандидат химических наук, e-mail: leites-elena@yandex.ru алпизарин, иначе - мангиферин из класса полифенольных соединений, имеющих структуру дибензо- $\gamma$-пирона. Алпизарин оказывает выраженное

\footnotetext{
*Данная статья имеет электронный дополнительный материал (приложение), который доступен читателям на сайте журнала. DOI: 10.14258/jcprm.2019024011s.

* Автор, с которым следует вести переписку.
} 
нефропротекторное действие при поражении канальцев нефрона и аутоиммунном гломерулонефрите, а также подавляет размножение всех подтипов вируса простого герпеса (Herpes simplex), опоясывающего лишая (Varicella zoster), цитомегаловируса, что позволяет сравнить алпизарин с синтетическими противовирусными препаратами ацикловир (зовиракс), бонафтон и др. [14, 15]. Препарат «Алпизарин» (мазь) зарегистрирован в 1985 г. и разрешен для применения в качестве противовирусного средства для местного применения. Отмечена хорошая переносимость алпизарина у детей и взрослых, отсутствие побочных эффектов, характерных для ацикловира [16]. Авторами [17] установлено, что показатели качества растительной субстанции касатика молочно-белого травы соответствует требованиям, предъявляемым к растительному сырью.

Актуальность исследований определена тем, что проблема хронических рецидивирующих вирусных заболеваний стоит особенно остро. Известно, что вирусом герпеса поражено более 90\% населения планеты. Применение лекарственных средств из растительного сырья - один из способов наиболее безопасного лечения заболеваний как при внешнем, так и при внутреннем использовании.

Помимо основных действующих веществ, содержащихся в растениях, имеет значение их элементный состав, поскольку макро- и микроэлементы играют важную роль для процессов жизнедеятельности организма в целом. Данные по элементному составу травы и экстракта Iris lactea Pall в литературе отсутствуют.

Цель работы - определение содержания ксантонов и элементного состава травы и сухого экстракта Iris lactea Pall.

\section{Экспериментальная часть}

Объектами исследования служили трава касатика молочно-белого, собранная в Забайкалье, закупленная в «Даурской заготовительной компании», и сухой экстракт, полученный методом водно-спиртовой экстракции [18-21], с последующим концентрированием и высушиванием экстракта на вакуумно-распылительной сушилке, предоставленной ООО «Хармс» (Псковская область).

Содержание макро- и микроэлементов определяли методом атомно-эмиссионной спектрометрии с индуктивно связанной плазмой на приборе Optima 7300 DV (Perkin Elmer). Растительное сырье предварительно измельчали, 1 г навески заливали азотной кислотой, разбавленной дистиллированной водой (1: 1$)$, проводили микроволновое разложение пробы. Минерализованную пробу охлаждали в вытяжном шкафу. После удаления оксидов азота проба представляла собой бесцветный раствор. Охлажденный до комнатной температуры раствор количественно переносили в мерную колбу, доводили до метки дистиллированной водой, перемешивали, затем проводили количественное определение элементов.

Для изучения биологически активных соединений в исследуемых объектах применяли тонкослойную (ТCX) и высокоэффективную жидкостную хроматографию (ВЭЖХ).

Для качественного определения флавоноидов травы и экстракта касатика молочно-белого методами ТСХ и ВЭЖХ готовили спиртовые извлечения и проводили гидролиз по следующей методике: 0.5 г сырья помещали в колбу с притертой пробкой, приливали 25 мл 10\% спиртового раствора серной кислоты, нагревали в течение 30 минут на водяной бане для протекания реакции гидролиза. Гидролизат фильтровали в мерную колбу вместимостью 25 мл и доводили до метки 70\% этиловым спиртом. 10 мл полученного гидролизата разводили дистиллированной водой в соотношении $1: 2$ и реэкстрагировали 10 мл смесью этилацетата и диэтилового эфира в соотношении $1: 1$. Реэкстракцию повторяли 5 раз. Объединенный реэкстракт промывали дистиллированной водой до нейтрального значения $\mathrm{pH}$ водных смывов и упаривали на водяной бане до полного исчезновения органического растворителя. Сухой остаток растворяли в 3 мл 95\% этилового спирта. Водно-этанольный рафинад, оставшийся после реэкстракции смесью этилацетата с диэтиловым эфиром, упаривали на водяной бане до удаления запаха органических растворителей и нейтрализовали гидрокарбонатом натрия, до $\mathrm{pH}=4-5$ (рафинад). Полученные гидролизаты, реэкстракты и рафинады анализировали методами ТСХ и ВЭЖХ.

На стартовую линию пластинки «Sorbfil ПТСХ-АФ-А-УФ» (1020) микропипеткой наносили по 20 мкл спиртовых извлечений травы и экстракта касатика молочно-белого, а также гидролизаты, реэкстракты, рафинады и растворы стандартных образцов рутина, кверцетина и алпизарина. Пластинку подсушивали на воздухе и хроматографировали восходящим способом в камере предварительно насыщенной в течение 24 ч смесью растворителей $н$-бутанол - уксусная кислота - вода (БУВ) (5: $1: 4)$, чаще всего применяемой для флавоноидов.

После достижения фронтом растворителя края пластинки ее вынимали, сушили, просматривали в УФсвете до и после обработки 5\% спиртовым раствором хлорида алюминия. 
Методом ТСХ в системе БУВ $(5: 1: 4)$ определены ксантон алпизарин и флавоноиды рутин и кверцетин, что согласуется с данными литературы.

Специфичность действия флавоноидов, а также растений, в которых они присутствуют, связана с особенностями химической структуры, поэтому важно было выяснить, в какой форме О- или С-гликозидов флавоноиды присутствуют в касатике молочно-белом траве и экстракте. С этой целью проведены исследования методом ВЭЖХ, на микроколоночном жидкостном хроматографе «МилиХром А-02» («ЭкоНова», Новосибирск, Россия), с УФ-детектором, колонкой $2 \times 75$ мм и сорбентом NucleoSIL-120-5-C18 с размером частиц 5 мкм. В качестве детектора использовали спектрофотометр. Хроматограмму фиксировали при температуре $35^{\circ} \mathrm{C}$ при длинах волн детектора 220, 254, 268, 300, 324, 360 (нм).

В качестве элюента А использовали 0.01\% раствор трифторуксусной кислоты, в качестве элюента Б ацетонитрил, скорость потока - 100 мкл/мин. Использовали градиентный режим: концентрация элюента Б менялась от 5 до 55\% при расходе 3000 мкл элюента А. Слабокислый характер анализируемых соединений, их способность растворяться в таких растворителях, как этиловый спирт, ацетонитрил, положены в основу выбора элюентов в качестве подвижной фазы. Указанные элюенты выбраны на основании данных литературы и собственных исследований, согласно которым они обеспечивают эффективное разделение флавоноидов.

Перед каждым экспериментом колонку регенерировали смесью ацетонитрила и трифторуксусной кислоты. Периодически снимали хроматограмму растворителей для подтверждения чистоты хроматографической системы (Blank analysis).

Для количественного определения алпизарина готовили водно-спиртовые извлечения из травы и экстракта из расчета $1: 10$ (для травы) и $1: 100$ (для экстракта). В колбу с притертой пробкой помещали 5.0 г измельченной травы или сухого экстракта, заливали 50 мл 40\% этилового спирта, помещали на водяную баню с обратным холодильником на 15 мин с момента закипания экстрагента в колбе, после чего охлаждали и фильтровали через бумажный фильтр. По аналогичной методике проводили извлечение 70\% этиловым спиртом.

Стандартный раствор алпизарина готовили из мази с содержанием алпизарина 5\%: 1.0 г вместе с вощаной капсулой помещали в коническую колбу вместимостью 100 мл, прибавляли 10 мл воды и нагревали на водяной бане до расплавления основы. Охлаждали колбу под струей воды и, не фильтруя, переносили водное извлечение в мерную колбу вместимостью 50 мл. Извлечение повторяли трижды порциями по 10 мл воды, переносили раствор в мерную колбу и доводили объем до метки, получали $0.1 \%$ раствор алпизарина (1.0 г мази содержит 0.05 г алпизарина); 0.05 и $0.025 \%$ растворы получали последующим разбавлением водно-этанольной смесью $(1: 1)$.

Количественное содержание алпизарина в пересчете на абсолютно сухое сырье в \% рассчитывали по формуле

$$
x=\frac{S_{x} \times C_{c m} \times V_{c m} \times 100}{(100-W) \times q \times S_{c m}}
$$

где $S_{x}$ - площадь пика исследуемого вещества, о.е. мин; $S_{c m}$ - площадь пика стандарта, о.е. мин; $C_{c m}-$ концентрация СО раствора, \%; $\mathrm{V}_{c m}$ - объем этилового спирта, мл; $q$ - масса сырья, г; $W$ - потеря в массе при высушивании сырья (влажность), \%.

\section{Обсуждение результатов}

Содержание химических элементов в надземной части Iris lactea Pall, определенное методом атомноэмиссионной спектрометрии с индуктивно связанной плазмой, и нормирование содержания приведено в таблицах $1,2$.

Таблица 1. Содержание макроэлементов в траве и экстракте Iris lactea Pall, мг/кг сухого вещества

\begin{tabular}{c|c|c}
\hline Элемент & Трава & Экстракт \\
\hline $\mathrm{K}$ & $9450 \pm 5$ & $23700 \pm 10$ \\
$\mathrm{Ca}$ & $8230 \pm 8$ & $3720 \pm 7$ \\
$\mathrm{Mg}$ & $945 \pm 3$ & $2020 \pm 7$ \\
$\mathrm{P}$ & $736.6 \pm 0.9$ & $1951 \pm 2$ \\
$\mathrm{Na}$ & $90.0 \pm 0.3$ & $2630 \pm 6$ \\
\hline
\end{tabular}


Таблица 2. Содержание химических элементов в надземной части Iris lactea Pall и нормирование содержания, мг/кг сухого вещества

\begin{tabular}{|c|c|c|c|c|c|c|c|c|c|c|}
\hline \multirow[b]{2}{*}{$\begin{array}{l}E \\
\frac{5}{0} \\
\sum_{0}^{0} \\
\bar{n}\end{array}$} & \multirow[b]{2}{*}{ 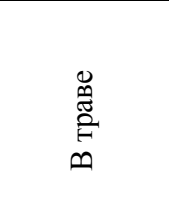 } & \multirow[b]{2}{*}{ 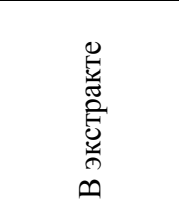 } & \multicolumn{8}{|c|}{ Нормирование содержания в растениях } \\
\hline & & & 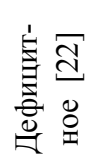 & 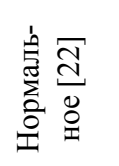 & 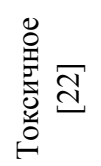 & 岂 & 离 & 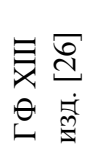 & 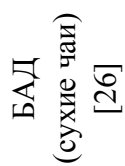 & 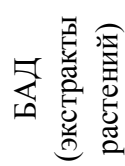 \\
\hline $\mathrm{Fe}$ & $298 \pm 3$ & $40.5 \pm 0.2$ & $<50$ & $50-240$ & - & - & 200 & - & - & - \\
\hline $\mathrm{Al}$ & $241 \pm 2$ & $13.3 \pm 0.3$ & - & - & - & - & - & - & - & - \\
\hline $\mathrm{Sr}$ & $131.2 \pm 0.3$ & $131.1 \pm 0.3$ & - & - & - & 113.3 & - & - & - & \\
\hline $\mathrm{Ba}$ & $50.8 \pm 0.2$ & $22.8 \pm 0.2$ & - & - & - & - & - & - & - & - \\
\hline $\mathrm{Mn}$ & $12.7 \pm 0.2$ & $19.1 \pm 0.2$ & $<20$ & $25-250$ & $>500$ & 104.8 & 205 & - & - & - \\
\hline B & $11.97 \pm 0.04$ & $32.55 \pm 0.04$ & - & - & - & - & - & - & - & - \\
\hline $\mathrm{Ti}$ & $10.7 \pm 0.3$ & $0.40 \pm 0.01$ & - & - & - & - & - & - & - & - \\
\hline $\mathrm{Zn}$ & $9.93 \pm 0.01$ & $8.88 \pm 0.12$ & $<20$ & $25-250$ & $>400$ & 53.3 & 30 & - & - & - \\
\hline $\mathrm{Cu}$ & $3.49 \pm 0.04$ & $0.85 \pm 0.01$ & $<5$ & $6-15$ & $>20$ & 9.9 & 8.0 & - & - & - \\
\hline $\mathrm{Ni}$ & $0.73 \pm 0.01$ & $0.50 \pm 0.01$ & - & $0-8$ & $>80$ & 8.1 & 2.0 & - & - & - \\
\hline $\mathrm{V}$ & $0.52 \pm 0.01$ & $<0.1$ & - & - & - & - & - & - & - & - \\
\hline Mo & $0.48 \pm 0.01$ & $0.32 \pm 0.01$ & $<0.1$ & $0.5-5$ & - & 0.88 & - & - & - & - \\
\hline As & $0.32 \pm 0.01$ & $0.50 \pm 0.01$ & - & - & - & - & 0.5 & 0.5 & 0.5 & 3.0 \\
\hline $\mathrm{Co}$ & $0.06 \pm 0.01$ & $0.03 \pm 0.01$ & - & $0-2$ & $>100$ & 0.34 & - & - & - & - \\
\hline $\mathrm{Sn}$ & $0.22 \pm 0.01$ & $<0.1$ & - & - & - & 0.18 & - & - & - & - \\
\hline $\mathrm{Pb}$ & $0.19 \pm 0.01$ & $0.10 \pm 0.01$ & - & $2-14$ & - & 4.1 & 1.25 & 6.0 & 6.0 & 5.0 \\
\hline $\mathrm{Se}$ & $0.18 \pm 0.01$ & $<0.1$ & - & - & - & 0.57 & - & - & - & - \\
\hline $\mathrm{Sb}$ & $0.09 \pm 0.01$ & $0.02 \pm 0.01$ & - & - & - & - & 0.06 & - & - & - \\
\hline $\mathrm{Ag}$ & $<0.1$ & $<0.1$ & - & - & - & - & - & - & - & - \\
\hline $\mathrm{Cr}$ & $<0.1$ & $<0.1$ & - & $0-0.5$ & $>1.3$ & 1.3 & 1.8 & - & - & - \\
\hline $\mathrm{Be}$ & $<0.05$ & $<0.05$ & - & - & - & - & 0.01 & - & - & - \\
\hline $\mathrm{Cd}$ & $<0.03$ & $<0.03$ & - & $0-0.5$ & $>100$ & 0.78 & 0.035 & 1.0 & 1.0 & 1.0 \\
\hline
\end{tabular}

Примечание. Прочерк - нет данных.

Из таблиц 1, 2 следует, что в в траве содержание $\mathrm{Cu}, \mathrm{Fe}, \mathrm{Ca}, \mathrm{Co}, \mathrm{Ti}, \mathrm{Se}, \mathrm{V}, \mathrm{Al}, \mathrm{Ba}, \mathrm{Sb}$ выше по сравнению с экстрактом, в то же время в экстракте содержание $\mathrm{P}, \mathrm{B}, \mathrm{Na}, \mathrm{Mg}, \mathrm{K}$ более чем в два раза превышает их объем в траве. Содержание $\mathrm{Pb}, \mathrm{Cd}, \mathrm{Cr}, \mathrm{Mn}, \mathrm{Zn}, \mathrm{Cu}, \mathrm{Ni}, \mathrm{Mo}, \mathrm{Se}$, Со в надземной части Iris lactea Pall ниже, Sn, As, Sb, $\mathrm{Sr}, \mathrm{Be}-$ на уровне, $\mathrm{Fe}$ - выше по сравнению со средними значениями для растительности континентов (табл. 2).

В соответствии со шкалой нормирования [22] содержание $\mathrm{Cu}, \mathrm{Mn}, \mathrm{Pb}, \mathrm{Zn}$ можно отнести к дефицитным, $\mathrm{Ni}, \mathrm{Co}, \mathrm{Cr}, \mathrm{Cd}, \mathrm{Mo} \mathrm{-} \mathrm{к} \mathrm{нормальным.} \mathrm{Количество} \mathrm{тяжелых} \mathrm{металлов} \mathrm{и} \mathrm{мышьяка} \mathrm{в} \mathrm{траве} \mathrm{и} \mathrm{экстракте} \mathrm{не} \mathrm{превы-}$ шает предельно допустимого содержания в лекарственном растительном сырье и лекарственных растительных препаратах $[25,26]$.

В траве и экстракте Iris lactea методами ТСХ и ВЭЖХ определено присутствие основныХ групп действующих веществ. В траве ириса молочно-белого присутствуют флавоноиды, дубильные вещества, кумарины, лимонная и винная кислоты, аминокислоты, в экстракте - флавоноиды, лимонная и винная кислоты, аминокислоты.

Предварительные исследования 70\% этанольного извлечения экстракта касатика методом ВЭЖХ показали наличие флавоноидов группы флавона с временем удерживания 13-14, 17.7, 19, 21, 24 мин., и имеющие

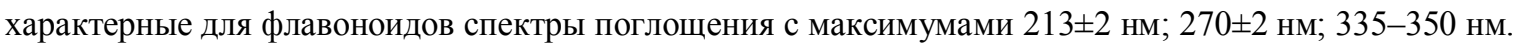

Для определения формы, в которой флавоноиды находятся в растении, проводили экстракцию веществ эфиром, этилацетатом и бутанолом. В бутанольном извлечении обнаружено наибольшее количество веществ группы ксантонов и флавоноидов. Флавоноиды содержатся в форме гликозидов, преимущественно группы апигенина. Для определения природы гликозидной связи проводили исследование гидролизата кислотного извлечения смесью диэтиловый эфир - этилацетат (1:1) (рис. 1). Вещество со временем удерживания 14.3 мин соответствует фенилпропеновой кислоте (кумаровой). Вещества со временем удерживания 25.5-26.2 мин соответствует метилированным формам кумаровой кислоты; 21.2 мин - кверцетину (спектр совпадает со стандартным образцом кверцетина); 24,2 мин - лютеолину. Обнаружено вещество со временем удерживания 
15.2 мин, спектр которого соответствует продуктам дегидратации и окисления сахаров: оксиметилфурфуролу, возможно, его метилированным формам.

Исследование водного остатка после этилацетатного извлечения показало наличие веществ со временем удерживания 18.2, 19.5 мин и 7.8 мин, которые соответствуют флавоноидам группы апигенина и продукту дегидратации сахаров.

На основании изучения группы флавоноидов методом высокоэффективной жидкостной хроматографии трава и экстракт касатика молочно-белого содержат идентичные по составу гидролизуемые флавоноиды, агликонами которых являются кверцетин и лютеолин (О-гликозиды) и флавоноиды группы апигенина (Сгликозиды) (рис. 2).

Идентификацию алпизарина проводили по времени удерживания с использованием стандарта алпизарина. Время удерживания составляет $12 \pm 0.5$ мин. Установлено, что алпизарин регистрируется в виде двойного пика, что позволяет предположить наличие близкого по строению к алпизарину вещества, которым может являться аналогичный ксантон или видоизмененный по какому-либо фрагменту алпизарин, вероятнее, с остатком сахарного компонента (см. электронное приложение). Данные вещества остаются и сохраняются после гидролиза в водной фазе, не извлекаются в эфир и этилацетат после гидролиза.

Количественное определение ксантонов, согласно данным литературы, проводится методом хроматоспектрофотометрии. Методика связана с нанесением ацетонового извлечения на пластинку с незакрепленным слоем сорбента, что, на наш взгляд, связано со значительными потерями определяемых веществ, поэтому разработана методика количественного определения ксантонов методом ВЭЖХ, приведенная выше.

Полученные методом ВЭЖХ результаты количественного содержания ксантонов в траве и экстракте касатика молочно-белого сравнили с данными нормативной документации содержания суммы ксантонов [1921]. Результаты приведены в таблице 3.

Как следует из таблицы, в экстракте Iris lactea Pall содержание суммы ксантонов выше, чем в траве, поскольку экстракт представляет собой концентрированное извлечение из травы. Содержание суммы ксантонов в экстракте почти в 2.5 раза выше, чем при определении данной группы веществ методом хроматоспектрофотометрии, что, по-видимому, можно объяснить усовершенствованной пробоподготовкой и меньшими потерями при их определении.

Рис. 1. Хроматограмма гидролизата кислотного извлечения травы касатика молочно-белого

Рис. 2. Хроматограмма спиртового извлечения травы и экстракта сухого касатика молочно-белого (хроматограммы идентичны)
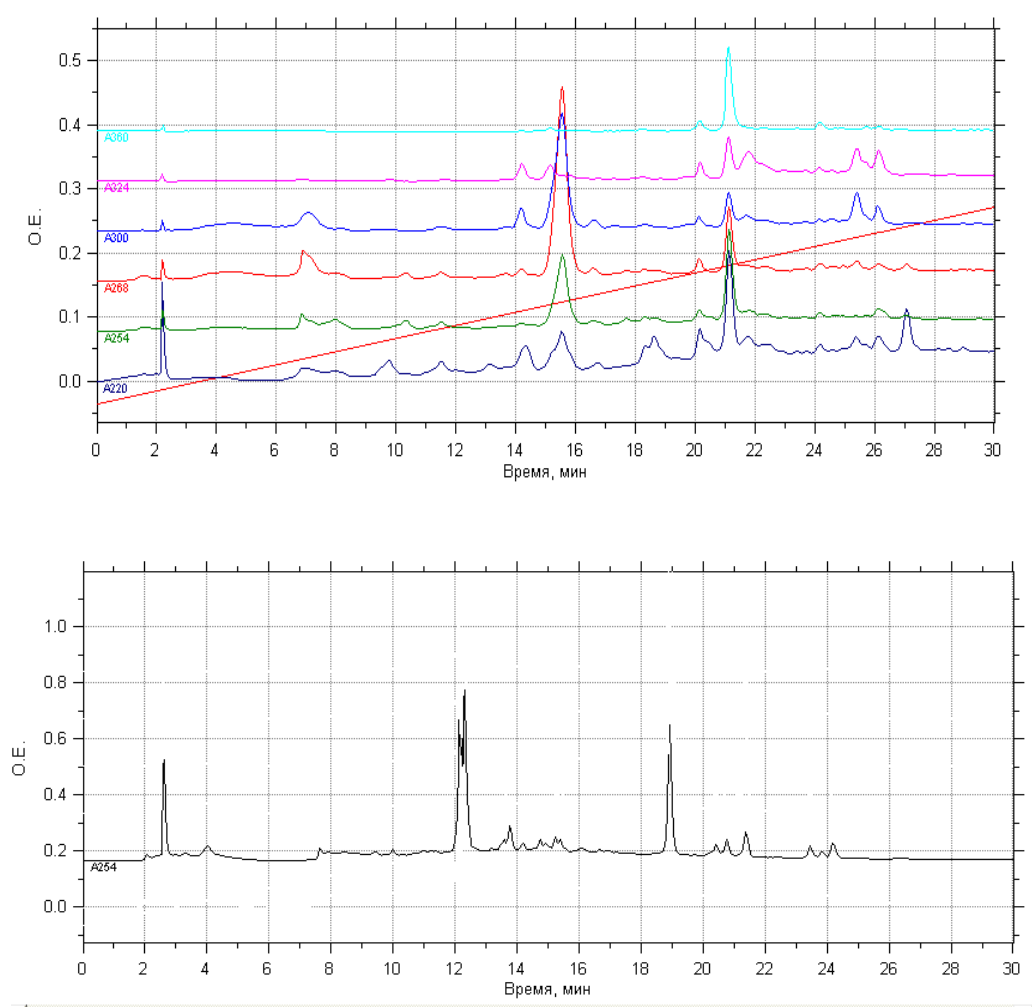
Таблица 3. Содержание суммы ксантонов в траве и экстракте Iris lactea Pall

\begin{tabular}{c|c|c|c}
\hline $\begin{array}{c}\text { Объект } \\
\text { исследования }\end{array}$ & $\begin{array}{c}\text { Содержание суммы } \\
\text { ксантонов, \% (СФМ) }\end{array}$ & $\begin{array}{c}\text { Содержание суммы ксанто- } \\
\text { нов (ВЭЖХ), \%, } \\
(40 \% \text { этиловый спирт) }\end{array}$ & $\begin{array}{c}\text { Содержание суммы ксантонов } \\
\text { (ВЭЖХ), \% } \\
\text { (70\% этиловый спирт) }\end{array}$ \\
\hline Трава & 1.1 & $1.04 \pm 0.02$ & $1.14 \pm 0.02$ \\
Экстракт & 0.75 & $1.66 \pm 0.01$ & $1.79 \pm 0.01$ \\
\hline
\end{tabular}

\section{Заключение}

Разработана методика определения ксантонов методом ВЭЖХ. Наибольшее содержание ксантонов, в пересчете на алпизарин, отмечается при применении в качестве экстрагента 70\% этилового спирта и составляет в траве Iris lactea Pall - 1.14\%, в экстракте сухом - 1.79\%, что почти в 2.5 раза превышает содержание, определенное методом хроматоспектрофотометрии.

Методом ТСХ в системе БУВ $(5: 1: 4)$ определены ксантон алпизарин и флавоноиды - рутин и кверцетин. В траве и экстракте ириса молочно-белого определен качественный элементный состав, основные группы действующих веществ: в траве присутствуют флавоноиды, дубильные вещества, кумарины, лимонная и винная кислоты, аминокислоты; в экстракте - флавоноиды, лимонная и винная кислоты, аминокислоты. Методом атомно-эмиссионной спектрометрии с идуктивно связанной плазмой определено содержание в экстракте и траве Iris lactea Pall Cu, Fe, Ca, Co, Ti, Se, V, P, B, Na, Mg, K, Al, Ba, Sb, Ag, Sr, Sn, Mo, Ni, Cd, Pb, $\mathrm{As}, \mathrm{Zn}, \mathrm{Be}, \mathrm{Mn}, \mathrm{Cr}$. Количество тяжелых металлов и мышьяка в траве и экстракте не превышает предельно допустимое их содержание в лекарственном растительном сырье и лекарственных растительных препаратах.

Результаты идентификации флавоноидов и ксантонов, содержащихся в траве и экстракте надземной части Iris lactea Pall, определение суммы ксантонов методом высокоэффективной жидкостной хроматографии могут быть применены при дальнейшем изучении других видов ирисов как источников ценных биологически активных соединений.

Экстракт и трава Iris lactea Pall являются перспективным источником для разработки препаратов, подавляющих размножение вируса простого герпеса и его подтипов.

\section{Список литературь}

1. Першина Н.А., Корыткова Е.П. Виды рода Iris L. (Iridaceae) во флоре Восточного Забайкалья // Ученые записки ЗабГГПУ. 2013. №1. С. 31-36.

2. Касатик молочно-белый - Iris lactea. Плантариум. [Электронный pecypc]. URL: http://www.plantarium.ru/page/view/item/20763.html (дата обращения: 02.04.2017).

3. Носаль М.А. Лекарственные растения и способы их применения в народной медицине. Л., 1991. С. $23-25$.

4. Минина С.А., Астахова Т.В., Пряхина Н.И., Абу Схела Г. Выбор состава и разработка технологии получения таблеток экстракта касатика молочно-белого // Химико-фармацевтический журнал. 2001. Т. 35. С. 24-26.

5. Блинова К.Ф., Шейченко В.И., Пряхина Н.И. Ацилированные С-гликозиды Iris lactea // Химия природных соединений. 1984. №5. С. 48-50.

6. Ланина Н.Е., Минина С.А., Пряхина Н.И. Изучение состава и сорбционной способности шрота травы касатика молочно-белого - Iris lacteal Pall. // Фармация. 2003. №1. С. 29-32.

7. Минина С.А., Пряхина Н.И., Чемесова И.И. Детский лекарственный препарат с экстрактом Касатика молочнобелого // Химико-фармацевтический журнал. 2008. Т. 1. С. 50-53.

8. Boltenkov E.V., Artyukova E.V., .Kozyrenko M.M. Species divergence in Iris series Lactae (Iridaceae) in Russia and adjacent countries based on chloroplast DNA sequence data // Russian Journal of Genetics. 2016. Vol. 52, N5. Pp. 507-516.

9. Luzhanin V.G., Whaley A.K. Development of embinin isolation technology from Iris lactea and the research of its pharmacological activity // Reviews of chimical pharmacology and drag therapy. 2016. Vol. 14S. Pp. 42.

10. Lv. H., Wang H., He Y., Ding C., Wang X., Suo Y. Separation and purification of four oligostilbenes from Iris lactea Pall. var. chinensis (Fisch.) Koidz by high-speed counter-current chromatography // Journal of Chromatography B. 2015. Vol. 988. Pp. 127-134. DOI: 10.1016/j.jchromb.2015.02.035.

11. Ланина Н.Е., Минина С.А., Пряхина Н.И. Групповой состав настойки надземной части Iris lactea Рall. и шрота после ее получения // Растительные ресурсы. 2003. Т. 39, №2. С. 99-105.

12. Тихомирова Л.И, Базарнова Н.Г., Микушина И.В., Долганова З.В. Фармаколого-биохимическое обоснование практического использования некоторых представителей рода Iris L. (обзор) // Химия растительного сырья. 2015. №3. C. 25-34. DOI: $10.14258 /$ jcprm.201503837.

13. Антипова Е.А., Несуненко И.В., Лейтес Е.А. Определение биологически активных соединений в экстракте и надземной части ириса молочно-белого // Новые достижения в химии и химической технологии растительного сырья: материалы VII Всероссийской конференции с международным участием. 2017. С. 249. 
14. Вичканова С.А. Эффективность алпизарина при герпесвирусных заболеваниях у детей и взрослых // Практическая фитотерапия. 2000. №1. С. 34-39.

15. Баринов Е.А., Пастушенков В.Л., Сапегин А.А. Новый иммуномодулирующий препарат экстракт касатика молочно-белого // Актуальные вопросы военно-морской и клинической медицины. СПб., 1995. 205 с.

16. Патент 2123349 (РФ). Способ получения комплекса, обладающего противовоспалительным, иммуномодулирующим и антигипоксическим действием / С.А. Минина, Т.В. Астахова, Н.И. Пряхина, Л.В. Пастушенков, Е.Е. Лесиовская, Т.И. Мельникова, Н.Ю. Фролова, В.А. Вавилова. 1998.

17. Ароян М.В., Каухова И.Е., Гончарова С.Б. Определение показателей качества растительной субстанции касатика молочно-белого травы // Научный результат. Медицина и фармация. 2017. Т. 3, №4. С. 17-20.

18. Минина С.А., Абу Схела Г.Р., Астахова Т.В., Пряхина Н.И., Зенкевич И.Г., Косман В.М. Технология получения сухого экстракта из надземной части касатика молочно-белого // Химико-фармацевтический журнал. 1999 . №4. C. $40-42$.

19. ТУ 9197-044-15197089-10, изм.1. Трава касатика молочно-белого. Удостоверение качества и безопасности от 02.08.2012. $2 \mathrm{c}$.

20. ТУ 9197-049-15197089-12. Экстракт касатика Iris lactea. Удостоверение качества и безопасности от 23.04.2012. 2 c.

21. ФСП 42-2005. Касатика молочно-белого трава Iris lactea Herba. 8 c.

22. Baker D.E., Chesnin L. Chemical monitoring of soil for environmental quality animal and health // Advances in Agronomy. 1975. Vol. 27. Pp. 306-366.

23. Ильин В.Б. Тяжелые металлы в системе почва-растение. Новосибирск, 1991. 151 с.

24. Добровольский В.В. Биосферные циклы тяжёлых металлов и регуляторная роль почвы // Почвоведение. 1997. №4. С. 431-441.

25. СанПин 2.3.2.1078-01. Гигиенические требования к безопасности и пищевой ценности продуктов. М., 2001.

26. Государственная фармакопея РФ. ХІІІ изд. М., 2015. Т. 1-3.

Поступила в редакциюю 17 апреля 2018 г.

После переработки 16 мая 2019 г.

Принята к публикаџии 17 мая 2019 г.

Для цитирования: Антипова Е.А., Лейтес Е.А. Определение содержания ксантонов и элементного состава надземной части и экстракта Iris Lactea Pall // Химия растительного сырья. 2019. №2. С. 189-196. DOI: 10.14258/jcprm.2019024011.

\section{Antipova E.A. ${ }^{l}$, Leites E.A. ${ }^{2 *}$ DETERMINATION OF THE CONTENT OF XANTONS AND THE ELEMENTAL COM- POSITION OF THE SUPERTHE EARTH AND EXTRACT IRIS LACTEA PALL

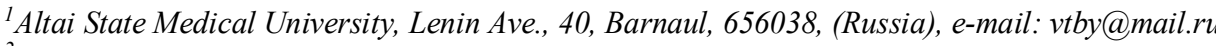 \\ ${ }^{2}$ Altai State University, pr. Lenin 61, Barnaul,656049, (Russia), e-mail: leites-elena@yandex.ru}

Iris lactea Pall (milky-white iris) belongs to the genus Iris L. of the Corridaceae family Iridaceae. In the form of an herb or an extract of Iris lactea Pall is found in some dietary supplements, it is included in the Alpizarin ointment, used as an antiviral agent. The use of antiviral drugs of plant origin is the safest method of treatment, given that about $90 \%$ of the population is affected by herpes. Data on the elemental composition of herbs and extracts of Iris lactea Pall are absent in the literature.

The purpose of the work is to determine the content of xanthones and the elemental composition of the herb and the dry extract of Iris lactea Pall.

The article presents the results of the determination of the main groups of active substances. The quantitative content of $\mathrm{Cu}, \mathrm{Fe}, \mathrm{Ca}, \mathrm{Co}$, Ti, Se, V, P, B, Na, Mg, K, Al, Ba, Sb, Ag, Sr, Sn, Mo, was determined by the method of atomic emission spectrometry with an ionically coupled plasma. $\mathrm{Ni}, \mathrm{Cd}, \mathrm{Pb}, \mathrm{As}, \mathrm{Zn}, \mathrm{Be}, \mathrm{Mn}, \mathrm{Cr}$, while the content of heavy metals and arsenic in the grass and extract does not exceed their maximum allowable content in medicinal herbal preparations. The following methods were determined by thin layer chromatography: Xanthone alpizarin and flavonoids rutin and quercetin. The method of high performance liquid chromatography (HPLC) revealed the presence of alpizarin and related xanthones.

According to the developed method for the determination of xanthones by the HPLC method proposed in this article, the highest content of xanthones, in terms of alpizarin, is in the grass milky white $-1.14 \%$, and in the dry extract $-1.79 \%$.

Milk-White Iris extract and herb are a promising source for the development of drugs that suppress the reproduction of the herpes simplex virus and its subtypes.

Key words: Iris lactea Pall, aerial part, alpizarin, apigenin, quercetin, luteolin, rutin, quercetin, herpes.

\footnotetext{
${ }^{*}$ Corresponding author.
} 


\section{References}

1. Pershina N.A., Korytkova Ye.P. Uchenyye zapiski Zabaykal'skogo gosudarstvennogo universiteta, 2013, no. 1, pp. 31-36. (in Russ.).

2. Iris milky white - Iris lactea. Landarium. [Electronic resource]. URL: http://www.plantarium.ru/page/view/item/20763.html (in Russ.).

3. Nosal' M.A. Lekarstvennyye rasteniya $i$ sposoby $i k h$ primeneniya $v$ narodnoy meditsine. [Medicinal plants and methods for their use in traditional medicine]. Leningrad, 1991, pp. 23-25.

4. Minina S.A., Astakhova T.V., Pryakhina N.I., Abu Skhela G. Khimiko-farmatsevticheskiy zhurnal, 2001, vol. 35, pp. $24-26$. (in Russ.).

5. Blinova K.F., Sheychenko V.I., Pryakhina N.I. Khimiya prirodnykh soyedineniy, 1984, no. 5, pp. 48-50. (in Russ.).

6. Lanina N.Ye., Minina S.A., Pryakhina N.I. Farmatsiya, 2003, no. 1, pp. 29-32. (in Russ.).

7. Minina S.A., Pryakhina N.I., Chemesova I.I. Khimiko-farmatsevticheskiy zhurnal, 2008, vol. 1, pp. 50-53. (in Russ.).

8. Boltenkov E.V., Artyukova E.V., .Kozyrenko M.M. Russian Journal of Genetics, 2016, vol. 52, no. 5, pp. $507-516$.

9. Luzhanin V.G., Whaley A.K. Reviews of chimical pharmacology and drag therapy, 2016, vol. 14S, pp. 42.

10. Lv. H., Wang H., He Y., Ding C., Wang X., Suo Y. Journal of Chromatography B, 2015, vol. 988, pp. 127-134. DOI: 10.1016/j.jchromb.2015.02.035.

11. Lanina N.Ye., Minina S.A., Pryakhina N.I. Rastitel'nyye resursy, 2003, vol. 39, no. 2, pp. 99-105. (in Russ.).

12. Tikhomirova L.I, Bazarnova N.G., Mikushina I.V., Dolganova Z.V. Khimiya rastitel'nogo syr'ya, 2015, no. 3, pp. $25-34$. DOI: 10.14258/jeprm.201503837 (in Russ.).

13. Antipova Ye.A., Nesunenko I.V., Leytes Ye.A. Novyye dostizheniya v khimii i khimicheskoy tekhnologii rastitel'nogo syr'ya: materialy VII Vserossiyskoy konferentsii s mezhdunarodnym uchastiyem. [New advances in chemistry and chemical technology of plant materials: materials of the VII All-Russian Conference with international participation]. 2017, pp. 249. (in Russ.).

14. Vichkanova S.A. Prakticheskaya fitoterapiya, 2000, no. 1, pp. 34-39. (in Russ.).

15. Barinov Ye.A., Pastushenkov V.L., Sapegin A.A. Aktual'nyye voprosy voyenno-morskoy i klinicheskoy meditsiny. [Topical issues of naval and clinical medicine]. St. Petersburg, 1995, 205 p. (in Russ.).

16. Patent 2123349 (RU). 1998. (in Russ.).

17. Aroyan M.V., Kaukhova I.Ye., Goncharova S.B. Nauchnyy rezul'tat. Meditsina i farmatsiya, 2017, vol. 3, no. 4, pp. 17-20. (in Russ.).

18. Minina S.A., Abu Skhela G.R., Astakhova T.V., Pryakhina N.I., Zenkevich I.G., Kosman V.M. Khimikofarmatsevticheskiy zhurnal, 1999, no. 4, pp. 40-42. (in Russ.).

19. TU 9197-044-15197089-10. Trava kasatika molochno-belogo. Udostovereniye kachestva i bezopasnosti ot 02.08.2012. [Specifications 9197-044-15197089-10. Grass iris milky white. The certificate of quality and safety from 02.08.2012.]. 2 p. (in Russ.).

20. TU 9197-049-15197089-12. Ekstrakt kasatika Iris lactea. Udostovereniye kachestva i bezopasnosti ot 23.04.2012. [Specifications 9197-049-15197089-12. Iris extract Iris lactea. The certificate of quality and safety from 23.04.2012.]. 2 p. (in Russ.).

21. FSP 42-2005. Iris milk white grass Iris lactea Herba. [Pharmacopoeial article of the enterprise 42-2005. Iris milk white grass Iris lactea Herba]. 8 p. (in Russ.).

22. Baker D.E., Chesnin L. Advances in Agronomy, 1975, vol. 27, pp. 306-366.

23. Il'in V.B. Tyazhelyye metally $v$ sisteme pochva-rasteniye. [Heavy metals in the soil-plant system]. Novosibirsk, 1991, 151 p. (in Russ.).

24. Dobrovol'skiy V.V. Pochvovedeniye, 1997, no. 4, pp. 431-441. (in Russ.).

25. SanPin 2.3.2.1078-01. Gigiyenicheskiye trebovaniya k bezopasnosti i pishchevoy tsennosti produktov. [Sanitary rules and regulations 2.3.2.1078-01. Hygienic requirements for safety and nutritional value of products]. Moscow, 2001. (in Russ.).

26. Gosudarstvennaya farmakopeya RF. [State Pharmacopoeia of the Russian Federation]. XIII ed. Moscow, 2015, vol. 1-3. (in Russ.).

Received April 17, 2018

Revised May 16, 2019

Accepted May 17, 2019

For citing: Antipova E.A., Leites E.A. Khimiya Rastitel'nogo Syr'ya, 2019, no. 2, pp. 189-196. (in Russ.). DOI: 10.14258/jcprm.2019024011 